\title{
Structured design in a power grid company
}

\author{
A. Y. Makarov, O. Y. Antonova \& S. V. Gurin \\ JSC “Bashkirian Power Grid Company”, Ufa, Russia
}

\begin{abstract}
The electric power industry is in fact a monopoly branch with a high grade of centralization of decision-making processes at the level of the executive body in charge of implementing the functional approach to management. Even though the management system seems to be integral and monolithic, it implies a number of controversies, which hamper effective development of the enterprise - the problem that may be resolved by implementation of the process approach to management.

This work shows the effective application conditions for the process approach to management of a power grid enterprise with client-orientation as the ultimate objective. It is proven that the relations between the technical unit and unit for realization of power supply services need to be changed, as well as difficulties are described which hamper $100 \%$ transition from functional to process approach.

With the consideration of the above it is proposed to implement elements of process approach for the functional structure of the power grid enterprise, as well as to delegate the authorities for elaboration and verification of operative management divisions. The methods of transition from vertical management to enhance effectiveness and efficiency of the company in the aggregate on the account of further decentralization and horizontal links are also shown Keywords: business process, process approach to management, functional units, client orientation.
\end{abstract}

\section{Introduction}

Application of the process approach for the purposes of company management is getting ever more popular, as more companies are formally claiming that they changed over to process management [1]. We may also find many literature references with the detailed descriptions of the relevant advantages. 
However, in practice, only those companies which operate in the bid markets, primarily in competitive industries may enjoy all the benefits of process management.

Power industry is in fact a monopoly with power grid companies acting as territorial monopolists. The basic products of power grids are the continuing power supply for the consumers thus ensuring the required performance and prompt technological connection of consumers.

\section{Customer-oriented approach of a power grid company}

Electric power industry is in fact a monopoly with power grid companies acting as territorial monopolists. The basic products of power grids are the continuing and reliable power supply for the consumers thus ensuring the required performance and prompt technological connection of consumers.

The demand on such services is steadily growing, and the growth rates are quite predictable. There are no changing requirements of the customers, regular updates of goods and services or racing trends of fashion here.

Till present, the power grid company as a territorial monopoly is not a customer-oriented company. Historically, the technical (production) group headed by Chief Engineer plays the major role here, as the ultimate goal of power grid companies is to continuously, reliably and faultlessly supply the consumers with electric energy of the required performance and characteristics. This task is accomplished due to proper maintenance of power grids, timely repairs, quick accidence response and others relevant technical measures.

The transition to market economy in Russia gave rise to a paradoxical situation in the power grid sector where, on the one part, the power grid enterprises are business entities registered as OJSC or LLC with profit earning and company's value adding as principal goals, and, on the other part, the government got stuck in obsolete directive methods of management, i.e. planning repairs in accordance with the set time-schedule, without taking into account the real condition of the equipment, using funds only for operative activities, but not for investments, approving investment programs without consideration of real needs of the region in power supply, based on costs of standard equipment unit, which hampers the modernization of this sector.

Now, the need in retention of earning power of the enterprise is more than urgent against the background of tough governmental tariff controls with steadily growing inflation rates. The only way out here is to increase net supply or reduce costs.

It is possible to increase net supply by building new opportunities for connection of new users, therefore, developing the customer-oriented infrastructure.

Reduction of costs in the power grid company is possible due to the reduction of principal costs items - payroll budgets, business losses and costs of repair. In this context it is obvious that reduction of costs without client-orientated policy 
may only worsen the reliability of power supply, increase idle times and, therefore, result in reduction of net supply and client's loyalty, as well as possible penalties.

\section{Application of the process approach to management of a power grid company}

Taking into account the importance of client-oriented approach for the power grid companies, as stated above, we may consider possible application of the process approach to management with focus on satisfaction of client's demands as the main objective.

With consideration of the requirements of client orientation the classic approach provides that the core company's processes are held by the sales executives being in charge for the entire value-added chain up to the client and controlling compliance with clients' requirements [2]. The core processes of the power grid company are "Realization of energy transportation services" and "Realization of technological connection services". All other processes are of supporting (service) or managing kind.

The process owner shall comply with strictest requirements, i.e.:

1. He shall control over compliance with client's requirements in different divisions for the whole workflow process.

2. He shall know the technologies of rendering of services; thoroughly understand the entire core business process as he becomes the customer for other processes (procurement, investments, maintenance and repair).

Let's consider the possible application of the process approach to management of the power grid company in terms of the process "Realization of technological connection services".

But first we would like to give some short information about the structure of the power grid company.

The structure includes three management levels - executive office, production divisions, and distribution zones. Each level of management is split into functional units - technical unit, unit for realization of power supply services, finance and economics, HR unit etc. Some functional units are represented at all three management levels, some at two or only one level. The divisions at different levels are functionally subordinated to each other within one functional unit, e.g., the HR department of the production division is functionally subordinated to the HR department in the executive office, while administratively this department is subordinated to the director of production division.

Below you may find an overview of the technological connection process. 


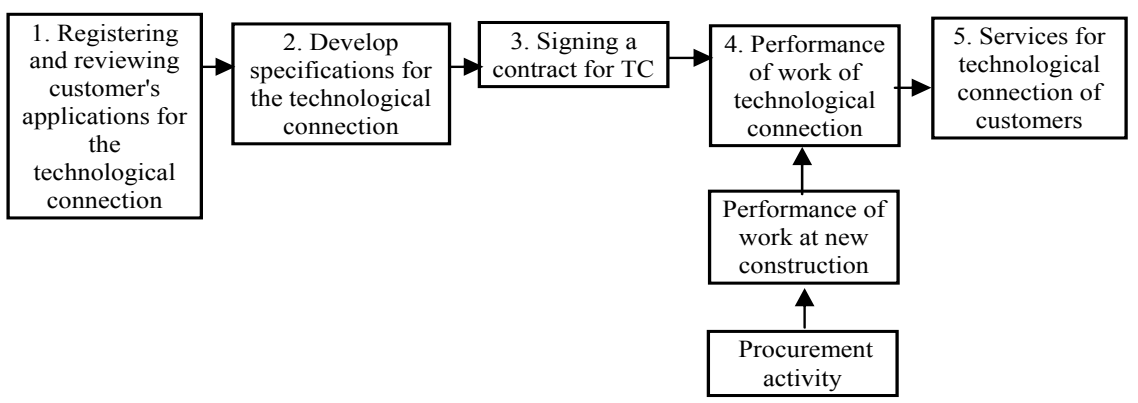

where:

$\mathrm{TC}$ - technological connection

TS - technical specifications

$\mathrm{MCW}$ - major construction works

Sub-processes 1 and 3 are to be implemented by the personnel subordinated to the Head for realization of power supply services.

Sub-processes 2, 4 and 5 are to be implemented with mandatory participation of personnel of technical unit which is subordinated to Chief Engineer. For subprocess A the personnel of the functional unit "procurement management" shall also participate in the process.

According to the classical process approach, the following processes shall be subject to consideration at the power grid company - maintenance and repair of power grids, procurement and logistics, investments as service processes with the in-house customer - unit for realization of power supply services. Therefore, the head for realization of power supply services being responsible for technological connection processes shall set the tasks to the Chief Engineer referring execution of major construction works and control over performance.

In this context the investment program shall be considered in context of the consumer's requirements and verified by the unit for realization of power supply services for compliance.

In fact, the leadership roles that were previously held by the technical unit passed after the implementation of client - oriented approach to the unit for realization of services. Will it adversary affect the continuity of power supply? No, it will not, as it is the objective of the second core business process of the power grid company "Realization of energy transportation services". For the successful implementation of this objective the unit for realization of services will require as customer faultless operation, minimum idle times, reduction of technical losses from the processes of technical maintenance and repair of power grids. These are actually the objectives that the technical unit was used to achieve.

Application of the process approach to the management of power grid company will help to resolve the major conflicts of functional management. 
In the case of functional management the Chief Engineer and Head for realization of services have to perform their own tasks - for the Chief Engineer implement investment and repaid program, ensure continuity of and faultless power supply, - for the Head for realization of power supply services - timely connect the consumer to power grid system and ensure gross revenues. As we may see from the above technological connection process the works for consumers' connection are performed by the personnel of technical unit. The same employees also perform technical maintenance and repair of power grids. When the volume of works of both kinds is too big, it is necessary to prioritize tasks which results in conflicts between two divisional heads.

In the case of process management these issues are resolved centrally by the head for realization of power supply services. He is the one to decide with consideration of the limited resources whether it "will cost more" for the company to extend the period to the next repair or not to connect the consumer taking into account the relevant risks, strategic development plans etc. Therefore, only one person will be responsible for finding balance between the tasks of the net supply increase, cost reduction and insurance of continuity and faultlessness.

Furthermore, for successful transition to process management and implementation of customer-oriented approach it is necessary to change the way of thinking not only of the company's management, but also of those who are in charge for definition of the national methods of governance.

\section{Delegation of tasks to the lower management levels for preparation of operational managerial decisions}

As mentioned above, while trying to cut average unit costs you will have to change the approach to management of the power grid company from functional to process one. Below we will propose an option for cutting fix costs within the framework of functional structure, however, with application of process approach within functional units and delegation of authorities for preparation and control of practical managerial decisions to lower management levels.

Let's have a look at the functional unit for procurement and logistics as an example. Within this unit we may see the business process with similar name which is composed by three processes - procurement planning, implementation of procurement procedures, logistics and supply of materials. Further we consider the process of procurement procedures.

The key account for procurement procedures is the technical unit. The objective of the process is to timely find and select the contractor for the procurement, logistics and supply of materials, relevant works and services at the minimum price. The solution is to define the pattern for selection of the winner or decision of the sole source.

The process is fully regulated; the sequence of functions is pre-defined and comprehensive. Generally, it looks like as follows:

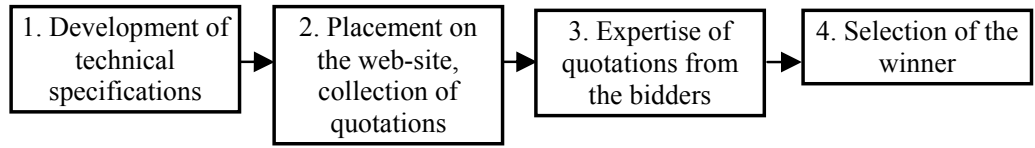


Table 1: $\quad$ Structure of functional procurement unit.

\begin{tabular}{|c|c|c|c|}
\hline \multirow[t]{2}{*}{ Process functions } & \multicolumn{3}{|c|}{ Persons in charge for performance of functions } \\
\hline & $\begin{array}{l}\text { In the case of de- } \\
\text { centralization }\end{array}$ & $\begin{array}{l}\text { In the case of } \\
\text { centralization }\end{array}$ & $\begin{array}{l}\text { In the case of } \\
\text { partial de- } \\
\text { centralization }\end{array}$ \\
\hline $\begin{array}{l}\text { Development of } \\
\text { technical } \\
\text { specifications }\end{array}$ & $\begin{array}{l}\text { Technical unit of } \\
\text { production } \\
\text { division }\end{array}$ & $\begin{array}{l}\text { Technical unit of } \\
\text { production division }\end{array}$ & $\begin{array}{l}\text { Technical unit of } \\
\text { production } \\
\text { division }\end{array}$ \\
\hline $\begin{array}{l}\text { Placement on the } \\
\text { web-site, } \\
\text { collection of } \\
\text { quotations }\end{array}$ & $\begin{array}{l}\text { Procurement unit } \\
\text { and material } \\
\text { supply of } \\
\text { production } \\
\text { division }\end{array}$ & $\begin{array}{l}\text { Procurement unit } \\
\text { and material supply } \\
\text { of executive office }\end{array}$ & $\begin{array}{l}\text { Procurement unit } \\
\text { and material } \\
\text { supply of } \\
\text { executive office }\end{array}$ \\
\hline $\begin{array}{l}\text { Expertise of } \\
\text { quotations from } \\
\text { the bidders }\end{array}$ & $\begin{array}{l}\text { Technical unit of } \\
\text { production } \\
\text { division }\end{array}$ & $\begin{array}{l}\text { Technical unit of } \\
\text { executive office }\end{array}$ & $\begin{array}{l}\text { Technical unit of } \\
\text { production } \\
\text { division }\end{array}$ \\
\hline $\begin{array}{l}\text { Selection of the } \\
\text { winner }\end{array}$ & $\begin{array}{l}\text { Procurement } \\
\text { committee of } \\
\text { production } \\
\text { division }\end{array}$ & $\begin{array}{l}\text { Procurement } \\
\text { committee of } \\
\text { executive office }\end{array}$ & $\begin{array}{l}\text { Procurement } \\
\text { committee of } \\
\text { executive office }\end{array}$ \\
\hline Advantages & $\begin{array}{l}\text { Quick decision- } \\
\text { making process } \\
\text { and quick } \\
\text { procurement } \\
\text { procedures }\end{array}$ & $\begin{array}{l}\text { Working out and } \\
\text { control over } \\
\text { compliance with the } \\
\text { unified } \\
\text { methodology; } \\
\text { reduction of costs } \\
\text { due to consolidation } \\
\text { of lots }\end{array}$ & $\begin{array}{l}\text { The control over } \\
\text { compliance with } \\
\text { the unified } \\
\text { methodology will } \\
\text { be maintained; } \\
\text { lower costs due to } \\
\text { consolidation of } \\
\text { lots will be } \\
\text { maintained; the } \\
\text { burden on } \\
\text { employees of the } \\
\text { executive office } \\
\text { will be released. }\end{array}$ \\
\hline Disadvantages & $\begin{array}{l}\text { It is difficult to } \\
\text { control over } \\
\text { compliance with } \\
\text { the uniform rules; } \\
\text { the procurement } \\
\text { costs increase due } \\
\text { to low volumes; }\end{array}$ & $\begin{array}{l}\text { Employees of } \\
\text { executive office are } \\
\text { pressed with too } \\
\text { much work, there } \\
\text { are communication } \\
\text { gaps at the level of } \\
\text { local managements; } \\
\text { the decision-making } \\
\text { process takes too } \\
\text { much time }\end{array}$ & $\begin{array}{l}\text { The decision- } \\
\text { making process } \\
\text { will accelerate but } \\
\text { not significantly. }\end{array}$ \\
\hline
\end{tabular}


In the context of preparation and adoption of managerial decisions the third function will be the preparation of the managerial decision and the fourth will be the adoption hereof. When carrying out the third function the experts compare bidders' quotations, compliance with the terms of reference and select the prospective winner. Within the fourth function, the heads of divisions meet to discuss and review the prepared expert opinions to take the decision.

However, the structure of functional procurement unit recently had several changes:

1. De-centralization period. Before the first reorganization of "Bashkirenergo" LLC each production unit performed procurement procedures independently up to a certain sum (about $80 \%$ ). All process functions were accomplished at the level of production divisions. There were no unified stock item catalogue, the uniform accounting schemes and methodology.

2. Centralization period. For enhancement of organizational procedures it was decided first to centralize tender procedures and then - operational procurement procedures. This objective was achieved thus enhancing control over the procurement procedures and transparency, but another problem arose. In lieu with large volume of works the employees of the executive office failed to meet the deadlines, that have some adversary effects on the quality.

3. Period of partial de-centralization. Transfer of some operational procurement tasks and authorities to carry out expertise of the quotations for centralized procurement to production divisions.

As a result of transfer of function of expertise of bidders' quotations from the first (executive office) to the second management level (production unit) the costs of procurement procedures are expected to decline due to the reduction of labor content of the highly paid employees of the executive office with no loss of quality of expertise.

\section{Conclusions}

Building up the structure of the power grid enterprise on basis of a customerbased approach is the most preferable way of development. For successful implementation of this idea it is expedient to make use of the process approach to management. The main processes in the company shall be realization of power supply services and technological connections. Technical maintenance and repair of power grids shall be considered as supporting processes.

With consideration of complexity of the issue of full transition to process management it is expedient to first apply its elements within functional units, inter alia to delegate authorities for preparation and verification of operative management solutions to the lower management levels. 
44 Energy Production and Management in the 21st Century, Vol. 1

\section{References}

[1] Repin V., Eliferov V., Process approach to management, Moscow: Mann, Ivanov и Feber, pp. 10-17, 2013.

[2] Koptelov A.K., Features of introduction process approach in Russia, www.club.cnews.ru/blogs/entry/osobennosti_vnedreniya_protsessnogo_pod hoda_v_rossijskih_usloviyah 